\title{
УДК:636.09:577.213:579.84
}

MANDZJa I. M.,

VOITA O. S., Ph.D, olga-1ua@ukr.net

State Scientific Control Institute of Biotechnology and Stains of Microorganisms, Kiev

\section{OPTIMIZATION OF AVIBACTERIUM PARAGALLINARUM MOLECULAR DIAGNOSTIC}

Diagnostic of bird's contagious illness must be timely and error-free. Sometimes only bacteriologic methods for some bacteria agents' identification is not enough. One of such bacteria is Avibacterium paragallinarum, that cause contagious poultry disease Infectious coryza. That why the aim of this study was to optimize method for Avibacterium paragallinarum identification by polymerase chain reaction. Selection of temperature and time models give opportunity to make reaction highly sensitivity and specific. Also reaction became economically profitable because of possibility to use combine samples.

Key words: Infectious coryza, polymerase chain reaction, molecular diagnostics, Avibacterium paragallinarum.

Introduction. Respiratory diseases - is the main pathologic processes of birds. Different viruses and bacteria can be causes of it. The most common of them are Newcastle disease, bird flu, infectious bronchitis, ornithobacteriosis etc. Infectious coryza (IC) caused by bacteris Avibacterium paragallinarum (early known as Haemophilus paragallinarum). A. paragallinarum is a Gram negative, polar staining, non-motile bacterium. In 24-48 hrs cultures, it appears as short rods or coccobacilli $1-3 \mu \mathrm{m}$ in length and $0.4-0.8 \mu \mathrm{m}$ in width, with a tendency for filament formulation. The organism undergoes degeneration within 48-60 hrs, showing fragments and indefinite forms [1]

IC is an acute respiratory disease of chickens. The clinical syndrome has been recognized since the 1930s. [2]. The disease occurs worldwide and causes economic losses due to an increased number of culls and a marked (10\% to more than $40 \%)$ drop in egg production, particularly on multiage farms. IC may occur in growing chickens and layers. The most common clinical signs are nasal discharge, facial swelling, anorexia, and diarrhea [3]. Also typical symptoms for IC are catarrhal inflammation of the mucous membranes of the nasal cavity, conjunctiva and airborne sinuses, hypodermic edema of the head. More rare cases is appearance of pneumonia.

Chicken is the natural host for A. paragallinarum and birds of all ages are susceptible. The disease is usually transmitted through drinking water contaminated with infective nasal exudates. Infection may also occur by contact and by air-borne infected dust and/or droplets [4]. After appearance of disease, bacteria can be in the bird organism during 6-12 months. That why always such birds are the source of infection.

The death of birds can arrive 10\% from livestock during acute process. Economic loss up to $40 \%$ associated with egg loss, especially in a top of production capacity, lack of young growth.

The most important differential diagnosis of IC are Rhinitis, Infectious larhyngotracheitis, pox, Newcastle disease. Diagnosis can be proofed only on the results of laboratory researches and identification of bacterial agent taken from nasal cavity or airborne sinuses.

The aim of this work was optimization of IC molecular laboratory diagnostics due to increasing of its specificity without decreasing of sensitivity, to make PCR reaction optimal for reagents produced in Molecular Biology Department of the SSCIBSM, make reaction capable to use combined samples that will reduce the cost for diagnostic.

Matherials and methods. Polymerase chain reaction gives opportunity to identify A. paragallinarum gen material in nasal and infraorbital swabs in the shortest time period. 
Swabs from the nasal cavity and infraorbital sinuses were taken from poultry with signs of respiratory infection from different farms for molecular diagnostic. There were two different types of analysis - with individual and combined samples. Individual samples were taken for research from nasal cavity or infraorbital sinus of one bird. Combined samples were taken from nasal cavity or infraorbital sinus of several birds, up to 5 heads.

For DNA extraction we used kits «DNA-sorb» that had been developed by Molecular Biology Department of State Scientific Control Institute of Strains of Microorganisms. DNA extraction was performed by guanidinium thiocyanate cell lysis. After lysis, there was the sorption of DNA into silicon dioxide in the suspension form, washing of silicon dioxide with laundering solutions №1 and №2, and DNA elution of the TE buffer.

A method for preparing a reaction mixture with the physical separation of PCR components was used with the aim of minimizing the formation of nonspecific dimmers of the primer-matrix and their amplification.

Specific primers [5] (table 1), Taq-polymerase, PCR buffer, deoxynucleoside triphosphate (dNTP) solution, mineral oil, autoclaved deionized water and extracted DNA were used for amplification.

Table 1

Sequences of specific oligonucleotides (primers) for identification $A$. paragallinarum

\begin{tabular}{|l|l|l|}
\hline Primer & Sequences of primers $\left(5^{\prime}->3^{\prime}\right)$ & Fragment \\
\hline hN1 & TGAGGGTAGTCTTGCACGCGAAT & \multirow{2}{*}{510 b.p. } \\
\hline hR1 & CAAGGTATCGATCGTCTCTCTACT & \\
\hline
\end{tabular}

Composition of the reaction mixture per one sample:

- $5 \mu$ of reaction buffer;

- $1 \mu \mathrm{l}$ of dNTP solution;

- $0,2 \mu 1$ of each primer solutions $\mathrm{hN} 1$ and $\mathrm{hR} 1$;

- $0,5 \mu \mathrm{l}$ of Tag Polymerase;

- $15,1 \mu \mathrm{l}$ of deionized autoclaved Water.

The reaction mixture volume per sample was $0,025 \mathrm{sm}^{3}$. Calculation of total reaction mixture volume based on samples quantity, negative control $(\mathrm{K}-)$ and positive control $(\mathrm{K}+)$. Mineral oil was applied to the surface of the reaction mixture.

PCR was carried out on the four channel thermocyclers «Tercyk» (DNA-technology, Russia) and «T1» (Biometra, Germany) due to program indicated in the table 2.

Table 2

\section{Amplification temperature regimen}

\begin{tabular}{|l|c|c|c|}
\hline Cycle & Temperature & Time, min & Quantity of cycles \\
\hline Start of denaturation & $95^{\circ} \mathrm{C}$ & 4 & 1 \\
\hline Denaturation & $95^{\circ} \mathrm{C}$ & 0,5 & 35 \\
\hline Annealing & $58^{\circ} \mathrm{C}$ & 0,5 & \\
\hline Elongation & $72^{\circ} \mathrm{C}$ & 0,5 & \\
\hline Final elongation & $72{ }^{\circ} \mathrm{C}$ & 4 & 1 \\
\hline Storage & $10^{\circ} \mathrm{C}$ & & \\
& & & \\
\hline
\end{tabular}


A horizontal electrophoretic tube (Bio-Rad Laboratories, USA) and an agarose gel with the addition of bromide etidium were used for electrophoresis. The electrophoresis tube was filled with Tris-borate (TBE) buffer ( $\mathrm{pH} 8.0$ ).

Marker with a range 100-1000 b.p. and intervals 100 b.p. was used for the better determination of the amplification product length.

Gel-viewer system «Gel DocXR Plus» (Bio-Rad Laboratories, USA) used for reviewing of DNA bands location on the electrophoregram.

\section{Results of the researches and discussion.}

Due to non specific clinical signs of IC, it must be differentiated from different illnesses. Bacteriological method for identification of IC pathogen A. paragallinarum is hard, have low level of specificity and take a lot of time. That why PCR method for identification of A. paragallinarum is actual and important. In our research we use literature source primers [5] and make PCR reaction highly specific (without appearance of non specific dimmers) and highly sensitive (to have an opportunity to investigate combined samples).

In the first stage we choose temperature and time regimen for amplification (table 2). Their main goal was to avoid formation of nonspecific dimmers of the primer-matrix and their further amplification. Also temperature and time regimen should not decrease sensitivity of method with chosen primers. As we see in the picture 1 interpretation of PCR results after electrophoregram all investigated samples contained gen of A. paragallinarum (1c, 2c, 3,) and nonspecific dimmers are absent.

\section{Accounting and interpretation of PCR results}

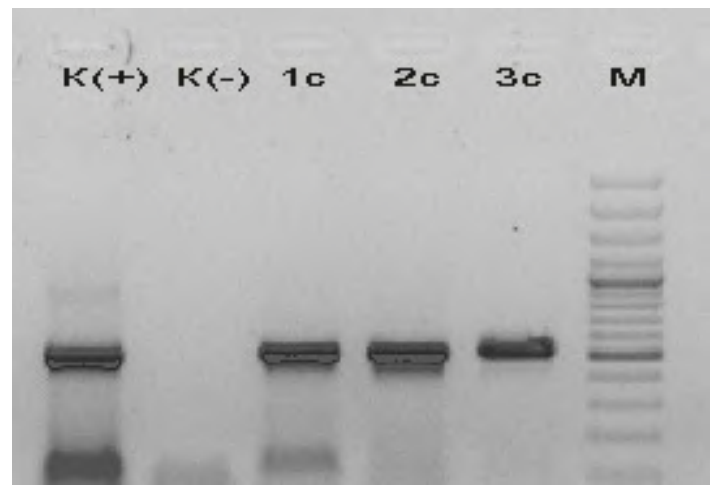

Picture 1. Electrophoregram examination of samples for the detection of microorganisms of the species A. paragallinarum.

$\mathrm{K}(+)$ - Positive control;

K(-) - Negative control;

M - Molecular weight marker (range - 100-1000 b.p., intervals - 100 b.p.);

1c - Single Sample;

$2 \mathrm{c}-3$ Samples in one tube;

$3 \mathrm{c}-5$ Samples in one tube.

The second step of research was to investigate combined samples. For this purpose we make single sample (Picture 1. 1c), 3 samples from different birds one of which was infected with A. paragallinarum (Picture 1. 2c) and 5 samples from different birds one of which was infected with A. paragallinarum (Picture 1. 3c).

As we can see our optimization of molecular diagnostic for identification of A. paragallinarum is highly specific and can identify presence of gen in combine samples (up to 5 samples in one tube). 


\section{Conclusions and perspectives of further research.}

1. Temperature and time regimen for amplification gave opportunity to provide PCR diagnostics of A. paragallinarum with reagents produced in Molecular Biology Department of SSCIBSM.

2. PCR parameters described in this article show increasing of specifity of reaction for A. paragallinarum identification. Absence of nonspecific dimmers of the primer-matrix and their amplification were not observed.

3. At the same time reaction sensitivity was not decreased even during usage of combined samples (up to 5 samples in one tube). It gave an opportunity to take swabs from the nasal cavity and infraorbital sinuses from five birds from one place in a farm. Even if one of these birds was infected A. paragallinarum, our PCR diagnostics will catch it. So, the cost of PCR diagnostic decrease in 5 times.

4. Main perspective for future research is possibility to identify A. paragallinarum from other infectious agents that cause similar clinical signs in birds quickly, error-free with minimal cost of examination.

\section{REFERENCES}

1. Yamamoto, R. (1991) Infectious coryza. Diseases of Poultry. 9-th ed.. B. W. Calnek, H. J. Barnes, C. W. Beard, W. M. Reid, and H. W. Yoder, Jr. et al. Iowa.: State University Press, 186-195 [in English].

2. Blackall P J, Matsumoto M, Yamamoto R. (1997) Infectious coryza. Diseases of poultry. 10th ed. B. W. Calnek, H. J. Barnes, C. W. Beard, McDougald L R, Saif Y M, editors. Iowa: State University Press; pp. 179-190 [in English].

3. Blackall, P. J. (1999) Infectious Coryza: Overview of the Disease and New Diagnostic Options. Clinical Microbiology Reviews. Vol. 12., 4, 627-623 [in English].

4. Akter S., Ali M., Das P. M. \& Hossain M. M. (2013) Isolation and identification of Avibacterium paragallinarum, the causal agent of infectious coryza (IC) from layer chickens in Bangladesh. Journal of the Bangladesh Agricultural University. Vol. 11, 1, 87-89 [in English].

5. Chen X, Miflin J. K, Zhang P, Blackall P. J. (1996) Development and application of DNA probes and PCR tests for Haemophilus paragallinarum. Avian Diseases. Vol. 40, 2, 398 - 407 [in English].

\section{ОПТИМИЗАЦИЯ МОЛЕКУЛЯРНОЙ ДИАГНОСТИКИ AVIBACTERIUM}

PARAGALLINARUM/ Мандзя И. Н., Войта О. С.

В данной статье проведена оптимизация метода молекулярной диагностики A. paragallinarum. Подобран оптимальный температурный и часовой режим амплификаиии. При этом иелью выбора температурных и часовых режимов было повысить специфичность реакции и не снизить ее чувствительность. Благодаря высокой чувствительности теста стало возможным использовать объединенные пробы. Так, в один анализ брали смывы с носовой полости и инфраорбитального синуса от пяти птиц с одной точки отбора образцов. Даже при наличии возбудителя у одной птицы, удавалось выявить A. paragallinarum в образцах. Это позволило существенно снизить стоимость проведения диагностических исследований.

Ключевые слова: инфекиионный ринит, полимеразная цеепная реакиия, молекулярная диагностика, Avibacterium paragallinarum. 


\section{OПТИМІЗАЦІЯ МОЛЕКУЛЯРНОї ДIАГНОСТИКИ AVIBACTERIUM PARAGALLINARUM / I. М. Мандзя, О. С. Войта}

Bступ. Інфекційний риніт курей - ие гостре респіраторне захворювання викликане збудником Avibacterium paragallinarum. Для постановки діагнозу необхідно диференціювати хворобу від інфекиійного ларинготрахеїту, інфекиійного бронхіту курей, ньюкаслської хвороби. Джерелом інфекиії є хвора та перехворіла птиця, оскільки збудник може циркулювати в організмі протягом 6-12 місяџів. Економічні збитки для господарств при виникненні інфекиійного риніту можуть сягати 40 \%. Тому вчасна та безпомилкова діагностика наявності збудника є нагальним питанням.

Метою даної роботи було удосконалити метод молекулярної діагностики A. paragallinarum, підвищити його спещифічність при використанні набору реактивів "ДНК-сорб», зберегти чутливість методу для можливості проведення діагностики об'єднаних про, що надасть можливість знизити вартість проведення досліджень.

Матеріали і методи. Використовували полімеразну ланцңюгову реакцію для виявлення гену збудника A. paragallinaruт в змивах з носової порожснини та інфраорбітальних синусів курей 3 ознаками респіраторних захворювань. Для постановки

Результати досліджень та обговорення. Проведено дослідження специифічності та чутливості полімеразної ланцюгової реакиї для визначення гену A. Paragallinaruт в досліджуванних зразках. Встановлено, зо обрані температурні та часові режими дають змогу уникнути виникненню неспеиифічних димерів, та використовувати в дослідженнях об'єднанні проби.

Висновки та перспективи подальших досліджень. Удосконалено метод молекулярної діагностики A. paragallinarum, а саме підібрано оптимальні часові та температурні режими для проведення полімеразної ланцюгової реакиї при використанні набору реактивів власного виробництва «ДНК-сорб». Підвищено специфрічність методу при збереженні високої чутливості, що дало змогу проводити реакиію з об'єднаними пробами. Завдяки иььому можлива своєчасна та точна діагностика збудника A. paragallinaruт за нижчою собівартістю проведення досліджень.

Ключові слова: інфекційний риніт, полімеразна ланцюгова реакція, молекулярна діагностика, Avibacterium paragallinarum.

\section{СПИСОК ЛІТЕРАТУРИ}

1. Yamamoto, R. Infectious coryza / R. Yamamoto // In B. W. Calnek, H. J. Barnes, C. W. Beard, W. M. Reid, and H. W. Yoder, Jr. eds. Diseases of Poultry. Iowa.: State University Press, Ames, - 1991. - 9-th ed. - P. 186-195.

2. Blackall, P. J. Infectious coryza / P. J. Blackall, M. Matsumoto, R. Yamamoto // In: B. W. Calnek, H. J. Barnes, C. W. Beard, L. R. McDougald, Y. M. Saif, editors. Diseases of poultry. - 1997. - 10-th ed. P. 179-190.

3. Blackall, P. J. Infectious Coryza: Overview of the Disease and New Diagnostic Options / P. J. Blackall // Clinical Microbiology Reviews. - 1999. - Vol. 12. - № 4. - P. 627-623.

4. Isolation and identification of Avibacterium paragallinarum, the causal agent of infectious coryza (IC) from layer chickens in Bangladesh / Akter S., Ali M., Das P. M., Hossain M. M. // Journal of the Bangladesh Agricultural University. - 2013. - Vol. 11. - № 1. - P. 87-89.

5. Development and application of DNA probes and PCR tests for Haemophilus paragallinarum / Chen X, Miflin J. K, Zhang P, Blackall P. J. // Avian Diseases. - 1996. - Vol. 40. - № 2. - P. 398-407. 